\title{
ALIGNMENT OF EFFORT: RECRUITMENT INTO UNDERGRADUATE AGRICULTURAL AND APPLIED ECONOMICS PROGRAMS
}

\author{
MOLLY ESPEY* \\ John E. Walker Department of Economics, Clemson University, Clemson, South Carolina \\ KATHRYN A. BOYS \\ Department of Agricultural and Resource Economics, North Carolina State University, Raleigh-Durham, \\ North Carolina
}

\begin{abstract}
Despite high employment rates and starting salaries for qualified graduates of agribusiness, agricultural, and applied economics (AAAE) programs, several AAAE departments have experienced years of low enrollment. This study offers insight into how AAAE programs can more effectively market themselves and recruit undergraduate students through analysis of a nationwide survey of college and department personnel and a statewide survey of high school students. Findings reveal important differences between students' preferred information and message sources and those currently used. Gaps in understanding of AAAE across administrative units are also identified. Specific program awareness, marketing, and student recruitment recommendations are offered.
\end{abstract}

Keywords. Agribusiness, agricultural economics, applied economics, marketing, program, recruitment, student, undergraduate

JEL Classifications. A21, A22, Q00

\section{Introduction}

Undergraduate enrollment and degree confirmation in agricultural economics and agribusiness programs lag behind overall degree confirmation nationwide (Perry, 2010). These programs produce barely half the graduates projected to be demanded in management and business positions in the agricultural, food systems, and renewable energy sectors for 2015-2020 (Goecker et al., 2015).

The authors thank former Clemson University undergraduate students Hannah Bagby, Stephanie Dolan, Ashleigh Duncan, Michelle Gottfried, and Seth Weaver for their research assistance; Amy Sanders and Katie Black of Clemson University and Audrey Denny of California State University-Chico for their input in development of the student services recruitment survey; Susan Hilton and David Rhyne for helping with trial runs of the student survey; Anthony Dillon and Lewis Huffman at the South Carolina Department of Education for facilitating access to high school teachers; and all the staff, faculty, teachers, and students who took the time to complete the surveys analyzed in this research.

*Email: mepsey@clemson.edu 
In addition, agricultural economics graduates are in demand by, and may earn more working in, industries other than agriculture (Artz, Kimle, and Orazem, 2014). In spite of this significant excess demand for their graduates, many agricultural and applied economics departments struggle to attract students, and some have recently faced faculty reductions, department mergers, or department elimination. Even with updated curricula, innovative program offerings, and a 2011 unemployment rate of just 1.3\% among all graduates (Georgetown University Center on Education and the Workforce, 2011), agricultural and applied economics programs sometimes still lack a sufficient number of undergraduate students to ensure their program sustainability. An improved understanding of how best to attract students into these fields is necessary to begin to address this shortfall.

With the goal of offering insight to improve recruitment of students into undergraduate agribusiness, agricultural, and applied economics (AAAE) programs, we analyze results of a nationwide survey of AAAE department and relevant college-level personnel regarding their recruitment efforts. The challenges and constraints in marketing such programs and the recruiting techniques considered to be most effective are identified and evaluated. These results are compared with findings from a simultaneously conducted survey of high school students regarding factors influencing their choice of college and major, as well as their level of knowledge of and interest in agricultural and applied economics. By improving understanding of how these departments are marketed and how these efforts align with students' focus in their college search process, recommendations are developed to improve program marketing. Particular attention is paid to the marketing and recruitment efforts of smaller academic programs. It is hoped that improved success in these activities will increase both the quantity and quality of undergraduate students enrolled in AAAE programs, help sustain programs facing enrollment challenges, and help meet the demand for qualified graduates of this discipline.

\section{Literature}

Most of the literature that has explored factors that influence undergraduate student enrollment decisions has focused on student perceptions and choices, rather than recruitment strategies and associated challenges. Studies analyzing student decisions about academic programs generally examine student choice of institution or major. Chapman (1981) identified specific student characteristics and external factors that guide college choice. Relevant student characteristics were found to include socioeconomic status, educational aspirations, aptitude, and prior educational performance. Influential external factors can be categorized into three groups: significant people, institutional characteristics such as size and location, and institutional recruitment efforts. Chapman's (1981) model of influence on institution choice has provided the theoretical foundation 
for much subsequent research including studies by DesJardins, Dundar, and Hendel (1999); Robinson, Garton, and Washburn (2007); Rocca and Washburn (2005); and Herren, Cartmell, and Robertson (2011).

\subsection{Recruitment into Agricultural Programs}

As student interest and employer demands change, recruitment strategies must be continually reassessed to effectively attract students onto campus and into specific degree programs. Studies examining recruitment in colleges of agriculture consistently identify parents as a strong influence on student enrollment decisions (Cole and Thompson, 1999; Robinson, Garton, and Washburn, 2007; Rocca and Washburn, 2005). Participation in on-campus recruitment programs, general campus visits, and personal contact with college representatives have also been found to be particularly influential in college choice decisions for agricultural students.

Although Cole and Thompson (1999) identified printed recruitment literature as being helpful in students' decision-making process, more recent studies by Robinson, Garton, and Washburn (2007) and Rocca and Washburn (2005) report information available on college and department websites as more significant. Although not surprising, these results indicate a significant change in preference of mode of obtaining education-related information among high school students.

Important differences also exist between students interested in careers in agriculture and those drawn to other programs within a university. Tarpley and Miller (2004) found that students in Utah who planned to major in agriculture tended to have more interest in natural sciences and had higher ACT Interest Inventory scores in technical and science areas than other students. Further, recent studies have found that students with no agricultural background have both a negative view of and very limited awareness of career opportunities in agriculture, but that their attitudes and interest improved with increased awareness (Baker and Abrams, 2011; Fraze et al., 2011).

\subsection{Recruitment into Agricultural and Applied Economics Programs}

The gap between opportunities and supply of qualified graduates has closed from $13 \%$ in 2000 to just over $7 \%$ for 2010-2015. Studies, however, indicate that virtually all of this reduction has been attributable to increased employment from graduates outside of agricultural economics (Gilmore et al., 2006; Goecker et al., 2015; Goecker et al., 2010). Given the availability of well-paying, numerous, and diverse jobs, the question remains as to why undergraduate enrollment in AAAE programs has not sufficiently expanded to fill this unmet industry demand. Compared with other departments in colleges of agriculture, AAAE departments require relatively limited physical resources and infrastructure. As such, physical capacity is not usually reported to be limiting. Instead, it is the relative lack of interest in these programs from qualified students that constrains their growth. 
The question then becomes, how might AAAE departments increase student interest in their programs? To date, there is little guidance available on this issue. Beyond the previously noted general studies exploring student selection of institution and major, no study has explicitly examined current AAAE program recruitment strategies. This study seeks to identify and explore alternative ways that recruitment and enrollment in AAAE programs can be fostered. Importantly and uniquely, this study holistically considers this issue from the perspectives of college of agriculture recruitment offices, AAAE departments, and prospective students. Through first an independent and then an integrated examination of these results, gaps and opportunities in the marketing of these programs are identified. Based on these results, concrete suggestions are developed as to how recruitment into AAAE programs can be enhanced.

\section{Methods}

This analysis proceeds through a two-fold approach that explores recruitment and program perceptions and preferences from the perspectives of both university staff involved with the recruitment process and students who are in the midst of making decisions about their higher education. The following discussion provides details of the qualitative and quantitative research approaches used to gain a holistic understanding of the perspective of each of these stakeholder groups.

\subsection{Recruitment Personnel}

A qualitative research phase was used to first gain a better, general understanding of recruitment considerations and challenges of those involved with college- and department-level recruitment. This was followed by a quantitative research phase during which a national survey of recruitment staff was used to complement these qualitative findings. To start, formal in-depth interviews were conducted with student services professionals at two institutions to gain insight into factors affecting the success of marketing university-level AAAE programs. Question development, participant recruitment, interview techniques, and data recording and analysis followed the recommendations of Seidman (2006). Although the interviewed individuals recruited undergraduate students for AAAE programs of similar size, their home institutions differed significantly in size, college administrative structure, and Carnegie classification and were located in different regions of the country (South Carolina and California). Recruitment of three types of students was considered: high school students, transfer students from community colleges, and students already on campus but registered in other majors or undeclared (internal recruitment). Issues surrounding attraction, retention, and attrition were explored. In addition to specific recruitment strategies, recruitment personnel were asked how they describe AAAE, both 
as a program and a profession, to prospective students and what challenges and constraints they face in the marketing of AAAE programs.

On the basis of previous research and our qualitative results, an electronic survey was then developed and pretested for distribution to college-level student services and academic department personnel involved with undergraduate recruitment. Survey development, pretesting, and distribution followed the recommendations offered in Dillman, Smyth, and Christian (2009). A distribution list was compiled of individuals in these roles at every institution in the United States and Canada that offers four-year undergraduate degree programs in agribusiness or agricultural, resource, or applied economics. A total of 184 contacts at 88 institutions were identified and provided with the survey using the online survey software Qualtrics (Qualtrics Labs, 2011).

This survey collected information regarding size, administration, and other characteristics of the institution, the relevant college and department, and AAAE program-specific information such as the number of incoming freshmen, the distribution of in-state and out-of-state majors, retention rates, and graduation rates. The type and extent of resources (human, monetary, etc.) dedicated to marketing and recruitment efforts within the AAAE department and the college, as well as recent trends in this resource availability and use were also explored. Questions concerning the distribution of recruiting effort between the university, college, and departments, and the allocation of time dedicated to prospective student outreach versus responding to direct student inquiries, were included. The use, challenges, and perceived effectiveness of specific recruiting techniques were also evaluated. Finally, respondents were asked to rank factors considered most important in attracting students into agricultural programs in general and into AAAE programs in particular. The qualitative and quantitative data collection was conducted between March 2011 and February 2012.

\subsection{Students}

Both qualitative and subsequent quantitative data collection approaches were also used to explore the perspectives of high school students in their search and decision process for a university-level academic program. Focus groups were first held to gain an understanding of the relevant considerations. The methodology employed for planning the focus groups, developing questions, meeting moderation, and analyzing and reporting their results was standard and followed that described in Morgan and Krueger (1998).

Eight focus group meetings were held between October and December 2010. As they had very recently gone through the university and program selection process, and retrospectively could reflect on the factors that affected their final decisions, freshman university and college students were recruited as participants 
to these meetings. ${ }^{1}$ In addition, to generally explore factors that influenced their choice of school and program, questions also gauged students' level of knowledge of agriculture and their interest in careers in AAAE programs. Each meeting was attended by between 6 and 10 individuals who were enrolled in a wide range of academic programs.

Based on focus group meeting results and other published research, an online survey was developed for distribution to high school students. Survey development, pretesting, and distribution followed the recommendations of Dillman, Smyth, and Christian (2009); this survey was also distributed through Qualtrics. At its outset, the survey collected demographic information about the students and their families, study habits, and academic performance. Respondents were asked about their plans after high school, and for those planning to go to a four-year college, questions were included about their intended institution, area of study, and search process. Specific factors relevant to their institution and program preferences, and the relative weight of these factors in their decision making, were also explored. Student understanding of "agriculture" and career opportunities within AAAE were also assessed.

Given the challenge with recruiting minors for participation in research studies, the survey was distributed in a relatively limited geographic area. Specifically, student participants throughout the state of South Carolina were recruited through high school business and economics teachers who were, in turn, recruited through the South Carolina Department of Education Business and Social Studies Education Associates.

The survey was released during multiple semesters to reach multiple cohorts of students (May 2011, November 2011, and May 2012). ${ }^{2}$ Screening questions and checks of the data were used to ensure that respondents participated only once. We conducted $t$-tests of the means of key variables to evaluate whether differences existed between responses collected during the data collection periods. Finding no significant differences, these data sets were pooled.

\section{Data and Analysis}

The following discussion presents an overview of characteristics of the respondents and in the case of university staff their programs and the administrative structure in which they operate.

1 Alternatively, students in their final year of high school and in the process of making their university decisions could have been recruited. Through informal interviews with both high school and freshman university students, however, it was observed that the ex post perspective of the freshman students offered a more complete inventory of student considerations. As such, although they were several months removed from having made their university and program decisions, given the purpose of these focus groups it was decided that for this research phase university freshman would be a more appropriate pool.

2 The survey instrument is available from the authors on request. 


\subsection{College and Department Staff}

Twenty-two student services staff and 19 departmental representatives completed the survey; this reflects an overall response rate of $22 \%$. Respondents were well distributed geographically and across major agricultural areas with representation from all U.S. Department of Agriculture (USDA) Farm Production Regions (USDA, Economic Research Service, 2010). Respondents were generally well established in their positions; on average, respondents from departments had been in their current role for 12.3 years, and college-recruiting staff had held their positions for 8.9 years.

Within academic departments, few resources are allocated to undergraduate student recruitment. A relatively small proportion of faculty contributed to recruitment activities in at least some manner (on average, $27 \%$ of faculty). Similarly, staff time dedicated to help with recruitment is limited; a majority of departments had either no or only a partial position of staff support to help with recruitment. In two instances, recruitment duties were split among the responsibilities of multiple staff members. Similarly, few financial resources are available for undergraduate recruiting by departments. In most cases, there was no explicit recruiting budget and/or no funding currently allocated to that budget. Among departments that dedicate funds to recruiting, the average allocation was $\$ 1,550$ (range $\$ 250$ to $\$ 5,000$ ). When reported, in a majority of cases, departmental respondents noted that their budgets had remained unchanged or had decreased in recent years. In two instances, departments noted that they have recently been increasing their allocation for recruitment expenses.

Not surprisingly, considerably more resources are available within college offices to support undergraduate student recruitment. The average reported college recruiting budget was $\$ 24,600$ (range $\$ 10,000$ to $\$ 48,000$ ). All college respondents noted that their budgets had either remained the same or had decreased (sometimes drastically) in recent years. In response to these constraints, many commented that they were attempting to be more focused and efficient in their recruiting efforts. For example, the extent of recruitment done through e-mail and web presence was reported to have increased, whereas travel, particularly to locations that were not significant sources of students, had decreased.

Respondents also provided insight into the relative responsibility for recruiting between university recruiting services, college-level offices, and department-level efforts. On average, the university's central recruiting office was reported to hold $41 \%$ of recruiting responsibility, $44 \%$ fell to colleges, and the remaining $15 \%$ fell to individual academic departments. Allocation of these responsibilities, however, varied considerably across institutions. In one example, it was reported that the college held full $(100 \%)$ responsibility for all recruiting activities. At the other end, in a case in which centralized offices were responsible for $80 \%$ of recruiting, college and departmental staff were each responsible for $10 \%$ of these efforts. AAAE departments generally held more limited recruiting responsibilities 
than university or college offices and were reported to be charged with $0 \%$ to $37 \%$ of student recruitment effort.

\subsection{Students}

In total, 633 high school students from across South Carolina completed the student survey. These individuals attended schools of varying sizes and were well distributed across rural, suburban, and urban locations. Respondents were equally distributed by gender $(50.7 \%$ male) and, on average, were 16 years of age. Importantly as well, there was no statistically significant difference between the composition of the racial makeup of respondents and that of similarly aged individuals in South Carolina. ${ }^{3}$ As such, survey respondents were deemed to be demographically reflective of high school students in this state.

The student survey results were evaluated using standard descriptive statistics and the probit method. A probit model was used to understand student interest level in several AAAE specialties. The theoretical foundations and implementation approach were standard and follow those well documented by other authors including Green (2011). The dependent variable in probit models was coded 1 if a student indicated "very interested" or "extremely interested" (rating of 4 or 5 on a five-point Likert scale) in each of several considered AAAE specialties; otherwise, it was coded 0 . The particular programs considered were selected to provide insight into fields commonly offered within AAAE programs. Specifically, student interest in applied economics, environmental and natural resource economics (ENRE), agricultural economics, and agribusiness management were considered separately. The analyzed sample was restricted to those students who planned to attend university.

Potential explanatory variables in the probit analyses were identified on the basis of previous literature, and earlier findings of this research and are summarized in the Appendix. Variables for which there was strong literature evidence of their relevance to student interest were included in a base model. Several variables were found to be uncorrelated with student interest in these programs and thus were excluded from the final analysis, including siblings currently or planning to pursue higher education, the relative rurality of the respondent's household, household income, current GPA, and whether the respondent's mother or father attended university.

Because of strong correlations among student participation in an agriculture class (Participate:AgClass), participation in agriculture-related extracurricular activities (Participate:AgExtra), and parent employment in the agriculture sector (PEmploy:Ag), only one of these variables was included in each analysis. As there was a relatively low correlation between student participation in environmentally focused classes (Participate:EnvClass) and extracurricular activities (Participate:EnvExtra; correlation 0.166, $P=0.011$ ), both of these

3 Comparison made with information from the U.S. Census Bureau (2010). 
variables were included in the final analysis. The fields in which students' parents are employed were found to be significant in influencing students' choice of major, and information gained through parents is weighted heavily by students in gathering information about university programs (described subsequently). As such, the specific fields of parent employment were included among the considered independent variables. A backward stepwise hierarchical approach was used to determine which among the course and extracurricular activity variables, and which types of parent employment, were most relevant to explaining student interest in each considered program.

\section{Results and Discussion}

Information collected from departmental staff reflects recruitment activities that are being used by AAAE departments nationally. It is recognized, of course, that student responses from a single state are not broadly generalizable. However, as recruitment activities can be adopted across locations, South Carolina high school students' responses to these recruitment approaches, regardless of where they are currently used, offer important insight for future practices to reach these students. Further, to the extent that high school students in South Carolina share demographic characteristics, Internet access, agricultural sector connections, ${ }^{4}$ and other characteristics with high school students in other Southern states, the opinions of these students can help inform recruitment efforts there as well.

University, college, and department recruiting activities are intended to be complementary and aim to recruit students to the university, college of agriculture, and department, respectively. Given their differing foci, these units frequently differ in their recruitment approaches and tactics. Our analysis begins with discussion of the factors thought by college and departmental respondents to affect student interest in agriculture and agricultural and applied economics. This is followed by a summary of our findings concerning high school students who indicated interest in studying agribusiness or agricultural economics in college. As students who express some interest in an academic program are more likely to explore it further, these students are a prime target for recruitment. Thus, identifying the background of these students and exploring the factors influencing their choices about college can help inform school and program marketing.

As with marketing any product, effectively marketing an academic program requires careful consideration of market segmentation, the targeting of suitable market segments, and positioning relative to competitor programs. By integrating

4 The connection a student would feel to the agricultural sector may be influenced by the extent to which he or she is exposed to this sector and is personally impacted by it. The relative rurality of a state and the proportion of a state's employment that is based in the agricultural sector are used as proxies for these measures. 
Table 1. Ranking of Factors Perceived to Be Important in Attracting Students into a Specific Academic Program

\begin{tabular}{lll}
\hline \hline $\begin{array}{l}\text { Rank of } \\
\text { Importance }\end{array}$ & Ranking by Academic Department Staff & Ranking by College Staff \\
\hline 1 & $\begin{array}{l}\text { Personal interest in subject matter } \\
\text { Students employed within } 1 \text { year of } \\
\text { graduation (\%) }\end{array}$ & $\begin{array}{l}\text { Personal interest in subject matter } \\
\text { Future career options }\end{array}$ \\
3 & Future career options & Experiential learning \\
4 & Knowledge from friend or relative & Scholarship availability \\
5 & Access to faculty and staff & Access to faculty and staff \\
6 & Scholarship availability & Knowledge from friend or relative \\
7 & Experiential learning & Students employed within 1 year of \\
& graduation $(\%)$ \\
8 & Time to graduate & Class size \\
9 & Class size & Time to graduate \\
\hline \hline
\end{tabular}

results from the qualitative and quantitative research phases, key insights are gained into each of these marketing actions. Information useful to improving market segmentation is offered in the following discussions of what influences student interest in academic programs, how AAAE is described to prospective students, and the characteristics of students who are particularly interested in AAAE programs. Although targeting is the prerogative of each department, findings presented in the assessment of who is interested in specific fields within AAAE programs will provide useful guidance for this decision. Aids to positioning a specific AAAE program, both relative to other AAAE programs and to other business or agriculture program options, are explored in a discussion of the use and perceived effectiveness of recruitment techniques. This discussion concludes by providing an overview of the challenges and opportunities of recruiting undergraduate students into AAAE programs.

\subsection{What Influences Student Interest in Academic Programs?}

Both department- and college-level personnel perceive students to be most strongly influenced in their choice of major by a passion for the subject matter, followed closely by career options. Department representatives believe the rate of employment of graduates in their field of study to be of slightly more importance to student recruitment than future career options. Knowledge of a particular school or program from a friend or relative and access to faculty and staff were also considered important by those in academic departments (Table 1).

Although college-level recruiters similarly ranked student personal interest, career options, and access to faculty and staff as important, they reported that experiential learning opportunities were of greater importance to students (ranked third) than did department-level recruiters (ranked seventh), whereas employment rate of graduates was not included in their ranking of top factors. 
Items ranked lower, by both college and department recruiters, in their perceived importance in attracting students into a specific academic program include class size, time to graduation, tuition and related costs, program availability, program rank, and absence of foreign language requirements.

\subsection{How Is AAAE Described to Prospective Students?}

High school students are novice consumers of academic programs; they are new to the market for this product and may not have others with experience to help inform their decision. Such consumers tend to be more open to descriptions that do not necessarily coincide with their prior understanding about a new product (Sujan, 1985) compared with expert consumers. Thus, messaging of what programs in AAAE are, what they offer, is arguably as important as how to reach potential students.

Colleges are the primary conveyers of general information about programs and services offered by the college, whereas both colleges and academic departments convey information to students and their parents about AAAE. When asked to describe "agriculture," college personnel tended to give very similar, but more succinct, descriptions than departmental respondents, with both capturing the breadth fairly clearly. In their description of agriculture, $41 \%$ of college personnel included mention of production, $59 \%$ mentioned food, and $24 \%$ mentioned fiber, but not one mentioned consumers or farms. Among departmental respondents, $29 \%$ mentioned production; $82 \%$, food; and $41 \%$, fiber. Farms or farming was included in the description offered by $24 \%$ of the respondents, and some description of consumers and marketing was included in $12 \%$ of responses. Definition differences are likely attributable to the focus of these units - college personnel represent a wide variety of departments, many of which are traditionally more focused on production such as animal or plant science, range studies, and forestry.

Arguably more important than projecting a unified perspective of agriculture is that departments and colleges have a consistent and holistic message about what is encompassed within the discipline of applied economics. When asked how they describe their school's AAAE program to prospective students, college recruiters focused first on the business of agriculture and secondly on the breadth of applications of the discipline. However, $70 \%$ percent of college recruiter respondents focused on a narrow application of economics to production agriculture. These recruiters appealed first to students' potential program interests (e.g., "If you have an interest in business ..."), then to their interests in the program's curriculum. Only $10.5 \%$ mentioned jobs or careers, and even then it was done so quite generally (“... able to work in any business setting," “dynamic careers"). In comparison, when departmental respondents were asked the same question, $80 \%$ explained how the program prepares students for a range of career opportunities and pointed out the high employment rates of graduates, with only $30 \%$ focusing primarily on 
opportunities in the agricultural sector. Further, those involved with departmentlevel recruiting discussed curriculum in the context of development of skills rather than strictly in terms of subject matter. This stands in strong contrast to college staff where only one respondent $(5 \%)$ expounded on skills development (“... develop decision-making, communication and interpersonal skills ...”).

Nonetheless, all college and departmental staff descriptions are more comprehensive than high school student respondents' view of both agriculture and, more specifically, AAAE. When asked what comes to mind when they think of agriculture, $45 \%$ of students replied "farming" or "farms." Fewer than $6 \%$ had a response that went beyond production to include any of the breadth of the agricultural sector from processing to retail sales, including approximately $3 \%$ who replied "food." Not surprisingly, students know even less about AAAE than agriculture. Just less than $20 \%$ of students surveyed were able to identify anything close to an actual job that someone with a degree in agricultural economics might get other than farming. Approximately $40 \%$ suggested farming, and another $40 \%$ were completely off base or simply had no idea. South Carolina is among the most rural states in the country; $33.7 \%$ of South Carolina's population lives in rural areas (U.S. Census Bureau, "Lists," 2010) compared with a national average of $19.3 \%$ (U.S. Census Bureau, "Urban," 2010). Further, there is almost a two-fold greater rate of employment in the agricultural sector in South Carolina than is the national average (U.S. Census Bureau, County Business Patterns, 2011). With many students living closer to and potentially being personally impacted by agricultural activities, students in this state could reasonably have equal or more awareness of this industry than those in other areas. If students in a relatively rural state know so little about agriculture, it is not unreasonable to think that students elsewhere know even less. Given how little students know about the field, AAAE marketing messages that include insights characterizing the discipline would be of use to this audience.

\subsection{Who Is Interested in AAAE Programs?}

Student interest in AAAE programs was correlated with a number of demographic and personal characteristics. Table 2 presents an examination of factors related to "very" or "extremely" high levels of student interest in university studies in applied economics, ENRE, agricultural economics, and agribusiness management programs. These results do offer useful insight into how recruitment efforts can be more specifically targeted. Students with a high interest in economics were found to have a high interest in each of the considered AAAE programs and in particular in an applied economics major. With the exception of applied economics programs, females are notably more interested in AAAE programs than are males. Further, African American students were significantly more inclined to be highly interested in agribusiness management programs than were other students. 
Table 2. Probit Analysis and Marginal Effects of Student Interest in Applied Economics, Environmental and Natural Resource Economics (ENRE), Agricultural Economics, and Agribusiness Management Programs

\begin{tabular}{|c|c|c|c|c|c|c|c|c|}
\hline \multirow[b]{3}{*}{ Variable } & \multicolumn{8}{|c|}{ Program } \\
\hline & \multicolumn{2}{|c|}{ Applied Economics } & \multicolumn{2}{|c|}{ ENRE } & \multicolumn{2}{|c|}{ Agricultural Economics } & \multicolumn{2}{|c|}{ Agribusiness Management } \\
\hline & $\begin{array}{l}\text { Coefficient } \\
\text { Estimates }\end{array}$ & $\begin{array}{l}\text { Marginal } \\
\text { Effects }\end{array}$ & $\begin{array}{l}\text { Coefficient } \\
\text { Estimates }\end{array}$ & $\begin{array}{l}\text { Marginal } \\
\text { Effects }\end{array}$ & $\begin{array}{l}\text { Coefficient } \\
\text { Estimates }\end{array}$ & $\begin{array}{l}\text { Marginal } \\
\text { Effects }\end{array}$ & $\begin{array}{l}\text { Coefficient } \\
\text { Estimates }\end{array}$ & $\begin{array}{l}\text { Marginal } \\
\text { Effects }\end{array}$ \\
\hline Constant & $\begin{array}{c}-2.008^{* * *} \\
(0.425)\end{array}$ & & $\begin{array}{c}-1.444^{* * * *} \\
(0.304)\end{array}$ & & $\begin{array}{c}-3.757^{* * *} \\
(0.425)\end{array}$ & & $\begin{array}{c}-3.837^{* * *} \\
(0.665)\end{array}$ & \\
\hline Female & $\begin{array}{c}0.185 \\
(0.376)\end{array}$ & $\begin{array}{c}0.021 \\
(0.043)\end{array}$ & $\begin{array}{l}0.616^{* *} \\
(0.297)\end{array}$ & $\begin{array}{l}0.1 .09^{* *} \\
(0.051)\end{array}$ & $\begin{array}{c}0.670^{*} \\
(0.387)\end{array}$ & $\begin{array}{r}0.082^{*} \\
(0.047)\end{array}$ & $\begin{array}{c}0.774^{* *} \\
(0.380)\end{array}$ & $\begin{array}{r}0.078^{*} \\
(0.037)\end{array}$ \\
\hline African American & $\begin{array}{c}0.158 \\
(0.463)\end{array}$ & $\begin{array}{c}0.018 \\
(0.053)\end{array}$ & $\begin{array}{r}-0.149 \\
(0.377)\end{array}$ & $\begin{array}{r}-0.026 \\
(0.066)\end{array}$ & $\begin{array}{c}0.536 \\
(0.476)\end{array}$ & $\begin{array}{c}0.066 \\
(0.058)\end{array}$ & $\begin{array}{l}1.022^{* *} \\
(0.446)\end{array}$ & $\begin{array}{r}0.103^{* *} \\
(0.044)^{*}\end{array}$ \\
\hline $\begin{array}{l}\text { Both Parents Attend } \\
\text { University }\end{array}$ & $\begin{array}{r}-0.697 \\
(0.435)\end{array}$ & $\begin{array}{r}-0.079 \\
(0.050)\end{array}$ & $\begin{array}{c}-0.683^{* *} \\
(0.317)\end{array}$ & $\begin{array}{c}-0.121^{* *} \\
(0.054)\end{array}$ & $\begin{array}{c}0.376 \\
(0.374)\end{array}$ & $\begin{array}{c}0.046 \\
(0.045)\end{array}$ & $\begin{array}{c}0.574 \\
(0.357)\end{array}$ & $\begin{array}{r}0.058^{*} \\
(0.035)\end{array}$ \\
\hline Participate: AgClass ${ }^{\mathrm{a}}$ & $\begin{array}{c}0.246 \\
(0.447)\end{array}$ & $\begin{array}{c}0.028 \\
(0.051)\end{array}$ & $\begin{array}{r}-0.162 \\
(0.330)\end{array}$ & $\begin{array}{r}-0.029 \\
(0.058)\end{array}$ & $\begin{array}{c}0.858^{*} \\
(0.492)\end{array}$ & $\begin{array}{c}0.106^{*} \\
(0.059)\end{array}$ & & \\
\hline Participate: AgExtra ${ }^{\mathrm{b}}$ & & & & & & & $\begin{array}{l}0.930^{* *} \\
(0.425)\end{array}$ & $\begin{array}{c}0.093^{* *} \\
(0.041)\end{array}$ \\
\hline Participate: EnvClass ${ }^{\mathrm{a}}$ & $\begin{array}{c}0.076 \\
(0.449)\end{array}$ & $\begin{array}{c}0.009 \\
(0.051)\end{array}$ & $\begin{array}{c}0.523 \\
(0.320)\end{array}$ & $\begin{array}{c}0.092^{*} \\
(0.055)\end{array}$ & $\begin{array}{c}1.075^{* *} \\
(0.483)\end{array}$ & $\begin{array}{c}0.132^{* *} \\
(0.057)\end{array}$ & $\begin{array}{l}0.994^{* *} \\
(0.439)\end{array}$ & $\begin{array}{c}0.100^{* *} \\
(0.043)\end{array}$ \\
\hline Participate: EnvExtra ${ }^{\mathrm{b}}$ & $\begin{array}{r}-0.038 \\
(0.601)\end{array}$ & $\begin{array}{r}-0.004 \\
(0.068)\end{array}$ & $\begin{array}{c}0.623 \\
(0.402)\end{array}$ & $\begin{array}{c}0.110 \\
(0.070)\end{array}$ & $\begin{array}{c}0.893^{*} \\
(0.480)\end{array}$ & $\begin{array}{c}0.110^{*} \\
(0.057)\end{array}$ & $\begin{array}{c}0.331 \\
(0.430)\end{array}$ & $\begin{array}{c}0.033 \\
(0.043)\end{array}$ \\
\hline Interest in Business ${ }^{\mathrm{c}}$ & $\begin{array}{r}-0.349 \\
(0.525)\end{array}$ & $\begin{array}{r}-0.040 \\
(0.059)\end{array}$ & $\begin{array}{r}-0.452 \\
(0.392)\end{array}$ & $\begin{array}{r}-0.080 \\
(0.068)\end{array}$ & $\begin{array}{r}-0.731 \\
(0.558)\end{array}$ & $\begin{array}{r}-0.090 \\
(0.067)\end{array}$ & $\begin{array}{r}-0.078 \\
(0.476)\end{array}$ & $\begin{array}{r}-0.008 \\
(0.048)\end{array}$ \\
\hline Interest in Economics ${ }^{\mathfrak{c}}$ & $\begin{array}{l}1.818^{* * *} \\
(0.535)\end{array}$ & $\begin{array}{l}0.206^{* * *} \\
(0.058)\end{array}$ & $\begin{array}{r}0.844^{*} \\
(0.442)\end{array}$ & $\begin{array}{c}0.149^{* *} \\
(0.075)\end{array}$ & $\begin{array}{c}1.170^{* *} \\
(0.575)\end{array}$ & $\begin{array}{c}0.144^{* *} \\
(0.068)\end{array}$ & $\begin{array}{c}0.923^{*} \\
(0.483)\end{array}$ & $\begin{array}{c}0.093^{* *} \\
(0.047)\end{array}$ \\
\hline PEmploy ${ }^{\mathrm{d}}$ : Manufacturing & $\begin{array}{c}0.372 \\
(0.415)\end{array}$ & $\begin{array}{c}0.042 \\
(0.047)\end{array}$ & $\begin{array}{c}-1.094^{* *} \\
(0.511)\end{array}$ & $\begin{array}{c}-0.193^{* *} \\
(0.089)\end{array}$ & & & & \\
\hline PEmploy: Construction & & & $\begin{array}{c}0.676^{* *} \\
(0.330)\end{array}$ & $\begin{array}{c}0.119^{* *} \\
(0.056)\end{array}$ & & & $\begin{array}{r}-1.091 \\
(0.803)\end{array}$ & $\begin{array}{r}-0.110 \\
(0.079)\end{array}$ \\
\hline
\end{tabular}


Table 2. Continued

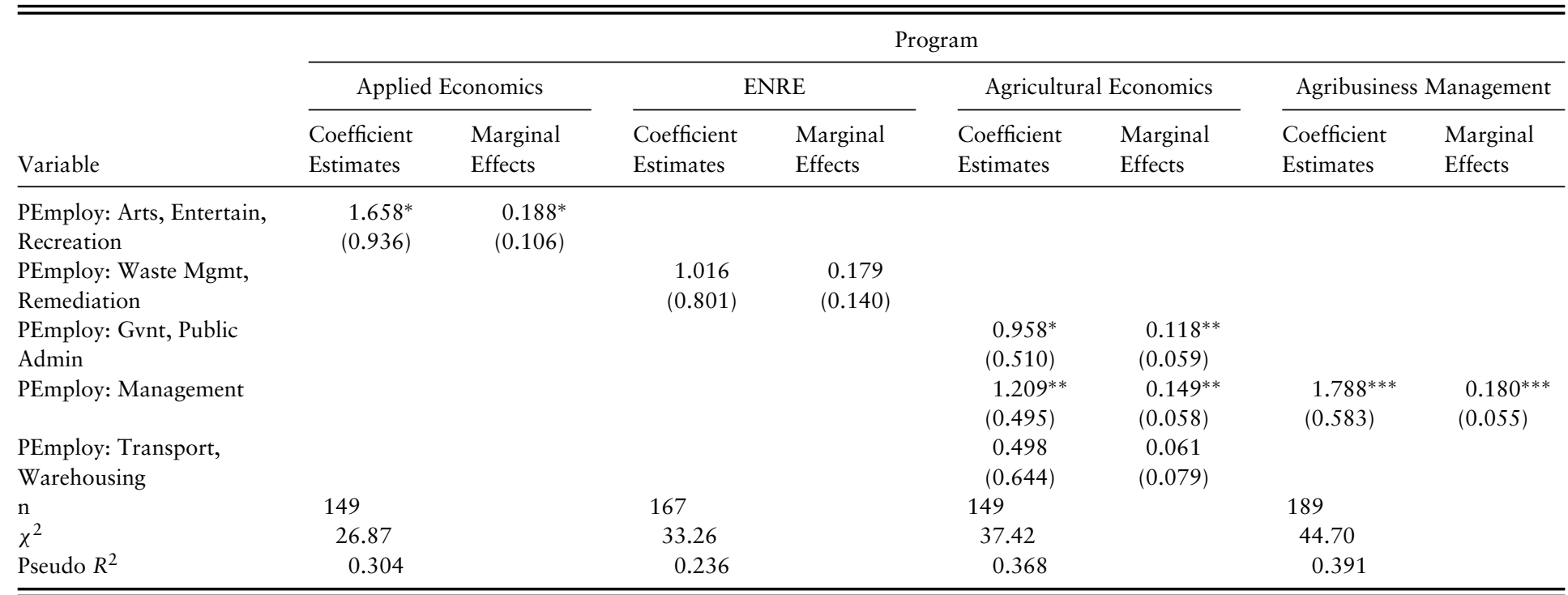

Note: Coefficients significant at the $1 \%(5 \%, 10 \%)$ level are denoted ${ }^{* * *}\left(* *,{ }^{*}\right)$, respectively.

${ }^{a}$ Currently or previously took a high-school class focused on this issue.

b Actively participate in at least one extracurricular group focused on this issue.

c Indicated either "very" or "extremely" interested in topic.

d PEmploy denotes that a parent is employed in the indicated sector. 
Participation in agriculture and environmental classes and extracurricular activities also proved to be an important correlate with AAAE program interest. Involvement with environmental extracurricular programs such as Envirothon or school environmental clubs was associated with increased interest in agricultural economics. Participation in agricultural classes corresponded to higher student interest in agricultural economics, and participation in environmental classes corresponded to higher interest in both agricultural economics and agribusiness management programs. Also, there was significant interest in agribusiness management programs among students who participated in agriculture-focused extracurricular activities such as 4-H and Future Farmers of America (FFA). A linkage between environmental interest and agricultural economics or agribusiness management programs is not typically made; these results suggest new and direct venues through which AAAE field recruitment efforts can be targeted.

Interestingly, and somewhat unexpectedly, cases in which both of the student's parents had attended university reported a significantly lower level of interest in ENRE programs and, on the margin, a higher level of interest in agribusiness management programs than those who had one or no parents attend a postsecondary program. The rationale for this outcome cannot be directly drawn from the study's findings. Focus group results, however, indicate that there is considerable family pressure for students to enroll in programs that have clear and good employment prospects. In several instances, this point was emphatically made by students whose parents had been burdened by, and in a few cases were still grappling with, student debt. To the extent that the employment opportunities and outcomes are less well known for programs such as ENRE, even students with an interest in the topic might be less inclined to select it as a program of study.

There were also some strong relationships identified between the field in which students' parents worked and their interest in AAAE programs. Students with a parent working in an arts, entertainment, or recreation field were significantly more interested in applied economics programs. A parent working in construction was correlated with higher student interest in ENRE programs; the opposite was true of students who had a parent working in a manufacturing industry. Parent employment in a management role was strongly and positively correlated with student interest in both agricultural economics and agribusiness management programs. A parent with a position in government or public administration also was positively related to agricultural economics program interest. These results offer some interesting avenues for program promotion. Given the importance of parent opinion to student program decision making, AAAE departments may find it useful to consider investing in relationships with firms or professional associations in these fields. Whether through directly promoting specific AAAE field activities (including programs) to these groups or building relationships with these groups to help develop awareness of these programs, targeted efforts to reach parents offer a useful new recruiting angle. 
The opinions of department and college personnel concerning factors that most influence student enrollment in AAAE programs is not fully consistent with these findings. These respondents reported that personal interest, parents' background, and having participated in high school agricultural classes were the most relevant influencers. Parent's background was significant in some unanticipated ways. Correlation was found between those enrolled in high school agriculture classes who planned to pursue a postsecondary education and interest in only agricultural economics programs.

Although these results indicate that students with strong economic interests are clearly a potential market for agricultural economics departments, students interested in general business and agriculture may hold important potential for AAAE departments as well. In further examination of the $34.2 \%$ of students who expressed strong interest ("very" or "extremely" interested) in business, $13.1 \%$ also indicated strong interest in agribusiness and agricultural economics. Also, among the $22.7 \%$ of surveyed students who expressed a strong interest in agriculture (in general), $29.0 \%$ also expressed strong interest in studying agribusiness management and $26.2 \%$ expressed strong interest in agricultural economics. Increasing awareness of AAAE programs among students engaged in activities in these broader areas is potentially a fruitful recruitment strategy.

\subsection{Use and Perceived Effectiveness of Recruitment Techniques}

Recruitment comes in many forms, from outreach to direct response to inquiries, and involves a variety of activities and materials. Because of their relative resource availability, college recruiters expend more effort on outreach, whereas department personnel reported dedicating more of their efforts to responding to direct inquiries.

Brown et al. (1999) found campus visits to be significant in recruiting students to a particular university; consistent with this, college-level staff place high importance on programs for accepted students. Every college respondent indicated that they host or participate in such programs, send material to high school students, and use student ambassadors in the recruiting process. ${ }^{5}$ Most indicated that they also attend on- and off-campus FFA or 4-H events, host or participate in university programs for prospective students, host or participate in agricultural activities for middle and high school students, and recruit from community or technical colleges.

Recruitment approaches used by departments varied somewhat from those favored by college-level recruiters. Favored departmental techniques include recruiting from within two-year schools, hosting or participating in programs for

5 The structure of the student ambassador program varied. In some cases, ambassadors were paid, whereas in others they were volunteers. The college of agriculture ambassador programs varied considerably in their size. Although on average 23 students were involved in these programs, participation varied from 10 to 75 participants. 
Table 3. Recruitment Techniques Used by Colleges and Agribusiness, Agricultural, and Applied Economics Departments

\begin{tabular}{|c|c|c|c|c|}
\hline \multirow[b]{2}{*}{ Technique } & \multicolumn{2}{|c|}{ Recruitment by Colleges } & \multicolumn{2}{|c|}{$\begin{array}{l}\text { Recruitment by } \\
\text { Departments }\end{array}$} \\
\hline & Percent Using & Rank & Percent Using & Rank \\
\hline $\begin{array}{l}\text { Attend Future Farmers of America (FFA) or } \\
\text { 4-H events off campus }\end{array}$ & 86 & $3^{*}$ & 46 & $8^{*}$ \\
\hline Attend FFA or 4-H events on campus & 86 & $3^{*}$ & 50 & 7 \\
\hline Contact accepted students by phone & 80 & 4 & 69 & $5^{*}$ \\
\hline $\begin{array}{l}\text { Contact prospective students by phone or } \\
\text { e-mail }\end{array}$ & 87 & 2 & 43 & $9^{*}$ \\
\hline $\begin{array}{l}\text { Host or participate in events for prospective } \\
\text { students }\end{array}$ & 86 & $3^{*}$ & 43 & $9^{*}$ \\
\hline $\begin{array}{l}\text { Host or participate in programs for } \\
\text { accepted students }\end{array}$ & 100 & $1^{*}$ & 71 & $4^{*}$ \\
\hline $\begin{array}{l}\text { Participate in agricultural activities for } \\
\text { middle and high school students }\end{array}$ & 79 & $5^{*}$ & 46 & $8^{*}$ \\
\hline $\begin{array}{l}\text { Partner with others such as central } \\
\text { admissions or FFA or 4-H advisors }\end{array}$ & 86 & $3^{*}$ & 80 & 2 \\
\hline $\begin{array}{l}\text { Recruit from community or technical } \\
\text { colleges }\end{array}$ & 86 & $3^{*}$ & 79 & 3 \\
\hline Recruit internally & 64 & $6^{*}$ & 92 & 1 \\
\hline Send materials to high school students & 100 & $1^{*}$ & 60 & 6 \\
\hline $\begin{array}{l}\text { Use social media to educate and send } \\
\text { announcements }\end{array}$ & 60 & 7 & 69 & $5^{*}$ \\
\hline Use student ambassadors & 100 & $1^{*}$ & 71 & $4^{*}$ \\
\hline Visit college fairs & 79 & $5^{*}$ & 69 & $5^{*}$ \\
\hline Visit high schools & 64 & $6^{*}$ & 38 & 10 \\
\hline Visit relevant community events & 57 & 8 & 69 & $5^{*}$ \\
\hline
\end{tabular}

Note: Asterisk indicates technique was tied in this rank.

accepted students, utilizing student ambassadors, visiting college fairs and relevant community events, using social media, and calling accepted students. The most commonly cited departmental recruiting technique is internal recruitment (92\% reported using this technique). Both colleges and departments typically also partner with others in recruiting, for example through collaboration with central admissions, tour guides, or FFA and 4-H advisors. Recruitment techniques used by colleges and departments are summarized in Table 3.

Given the scarcity of recruitment time and other resources, it is important to consider which among these techniques are the most effective. Collegelevel recruiters ranked the use of student ambassadors, contacting accepted students through phone calls, hosting or participating in programs for accepted students, using social media to educate and send announcements, and partnering with other organizations as the most effective recruiting techniques. Among departmental respondents, however, recruiting from community or technical 
Table 4. Recruitment Techniques Rated Most Effective by Colleges and Agribusiness, Agricultural, and Applied Economics Departments

\begin{tabular}{ll}
\hline \hline Among Colleges & Percent Selecting \\
\hline Using student ambassadors & 50 \\
Contacting accepted students by phone & 43 \\
Hosting or participating in programs for accepted students & 36 \\
Using social media to educate and send announcements & 36 \\
Partnering with others & 36 \\
\hline Among Departments & Percent Selecting \\
Recruiting from community or technical colleges & 58 \\
Partnering with others & 50 \\
Using student ambassadors & 50 \\
Contacting accepted students by phone & 36 \\
Using social media to educate and send announcements & 36 \\
\hline \hline
\end{tabular}

colleges had the highest rating for effectiveness, followed by partnering with others, using student ambassadors, contacting accepted students by phone, and using social media to educate and send announcements. Many of these approaches offer recruits the benefit of personal contact with students who are currently enrolled in the college; it was strongly felt that this is an important and, in the view of some, perhaps the best recruiting technique.

The important role of student ambassadors to recruitment is worth emphasizing. Every college respondent indicated their college used student ambassadors for both on- and off-campus recruitment events, as well as to assist with other college functions. For example, student ambassadors often assist in hosting activities for prospective students during on-campus visits (including giving tours), educating other students about careers in agriculture, and to contact prospective students. Departmental student ambassadors were not reported to be as frequently used, but when present they filled roles similar to college ambassadors.

Neither group rated attending on-campus FFA or 4-H events, hosting or participating in programs for middle or high school students, or visiting relevant community events as among the most effective tools. The techniques most highly rated by departmental- and college-level staff are summarized in Table 4.

The greatest differences between college and departmental responses relate to participation in programs for accepted students and recruiting from community and technical colleges. College-level recruiters report that the former is relatively effective, whereas departments feel more strongly about the latter. This difference likely arises from the focus of each recruiter group. College personnel represent all departments in the college with a focus on bringing them into the university and college. With a much narrower goal of recruiting into a specific program, departments report that targeting students through specific courses or targeting 
Table 5. Primary Sources Accessed by Students to Obtain Information about Colleges and Universities

\begin{tabular}{lll}
\hline \hline & $\begin{array}{l}\text { Breadth of Use (\% of } \\
\text { respondents who use } \\
\text { source) }\end{array}$ & $\begin{array}{l}\text { Depth of Use (average \% of } \\
\text { information gathered from } \\
\text { this source among users) }\end{array}$ \\
\hline Wource & 73.6 & 31.6 \\
Website & 59.6 & 20.8 \\
Brochts/guardians & 56.0 & 17.9 \\
High school guidance counselor & 42.6 & 15.3 \\
Friend & 39.0 & 12.9 \\
Other family members & 38.8 & 12.1 \\
High school teacher/coach & 37.3 & 15.5 \\
Sibling & 34.4 & 13.2 \\
Tour/campus visit & 31.1 & 19.6 \\
College fair & 26.8 & 11.8 \\
College Board & 25.4 & 14.3 \\
Princeton Review & 12.7 & 8.7 \\
Other sources & 5.7 & 28.6 \\
\hline \hline
\end{tabular}

community college students who have already expressed interest in transferring to a related university program is more effective. This likely also reflects more efficient use of limited resources.

To complement this information, students were queried as to which information sources they used to obtain information about potential programs and schools. A wide variety of sources were considered, and both the breadth of use and the extent to which users relied on information from each source were evaluated. Results are presented in Table 5 . Websites, followed by printed materials and campus visits were the most widely accessed information sources offered by universities. Program websites are the most extensively relied on among all sources. Third-party academic program information providers such as College Board and Princeton Review were also widely accessed.

The extent to which family members and other influencers are turned to for information about university programs is worth highlighting. Although it is not surprising that parents, friends, guidance counselors, coaches, and "others" (extracurricular program leaders, religious community leaders, etc.) were turned to for guidance, these individuals were also deeply trusted information sources. Indeed, several of these sources trump those provided by the university in the extent to which they were relied on by students in their decision making. As the information shared by these influencers may be dated, incomplete, or inaccurate, this finding underscores both the importance of disseminating program information to influencers and the potential benefits of actively enlisting their support in recruitment efforts. 
Table 6. Summary of Recruitment Recommendations for Agribusiness, Agricultural, and Applied Economics (AAAE) Departments

\begin{tabular}{|c|c|}
\hline Recruitment Technique & Recommendations \\
\hline Develop recruitment partnerships & $\begin{array}{l}\text { Develop relationships with: } \\
\text { - Future Farmers of America and 4-H advisors } \\
\text { - High school agriculture, business, and economics teachers } \\
\text { - Agricultural industry firms to connect with parents of } \\
\text { prospective students } \\
\text { - Alumni and industry contacts }\end{array}$ \\
\hline Student ambassadors & $\begin{array}{l}\text { - Encourage student involvement in college ambassador programs } \\
\text { - (Further) develop AAAE ambassador program }\end{array}$ \\
\hline Improve website design & $\begin{array}{l}\text { Visually appealing, updated, and easy to navigate } \\
\text { Links with prospective student information concerning: } \\
\text { - Career opportunities } \\
\text { - Job placement rates } \\
\text { - Current student testimonials } \\
\text { - Departmental and college scholarships }\end{array}$ \\
\hline $\begin{array}{l}\text { Enhance coordination with } \\
\text { college and university recruiters }\end{array}$ & $\begin{array}{l}\text { Focus description of degree program on: } \\
\text { - Career opportunities } \\
\text { - Employment rates } \\
\text { - Program options }\end{array}$ \\
\hline $\begin{array}{l}\text { Develop informational materials } \\
\text { for recruitment partners }\end{array}$ & $\begin{array}{l}\text { Design and disseminate informational materials for student } \\
\text { advisors, teachers, and counselors } \\
\text { - Highlight content as noted for "Improve website design" }\end{array}$ \\
\hline Social media & $\begin{array}{l}\text { Sought for notices about events and department successes } \\
\text { - Judicious use of various tools }\end{array}$ \\
\hline
\end{tabular}

\subsection{Challenges and Opportunities in Recruiting into AAAE Programs}

Both college and departmental personnel indicate that a general lack of interest in agriculture, misperceptions about agriculture, and lack of knowledge of career options are significant constraints to increasing undergraduate enrollment in AAAE programs. Competition with business programs and the difficulty in distinguishing AAAE from general business and economics, other than by the various modifiers that might precede "economics," were also identified as recruitment challenges.

Importantly, this study offers insight into several opportunities that AAAE department and college recruitment efforts can more fully exploit. These approaches can be broadly categorized as opportunities through people, places, partners, and product. Specific recruitment recommendations for academic departments stemming from these opportunities are summarized in Table 6 and are discussed subsequently.

\subsubsection{Recruiting Opportunities: People}

Consistent with previous literature, our results indicate that high school students are most strongly influenced in their choice of university major by their parents, followed by other family members, teachers and guidance counselors, and 
then friends. Departments and colleges can establish relationships with parents through outreach in the form of direct contact (direct mail), social media (news feeds, etc.), and their participation at hosted events. Extension outreach may also be an effective way to reach potential recruits through relationships established with prospective students' parents.

The value placed on student ambassadors by college-level staff, as well as the importance that high school students place on current student testimonials and personal contacts in deciding on their major, suggests that AAAE departments would benefit from encouraging more of their majors to become involved in college ambassador programs and/or (further) developing their own department student ambassador program.

Recruiters for AAAE programs are cautioned to be sensitive to gender and minority student issues. Although female high school students were more interested in AAAE programs than were male students, at the undergraduate level their enrollment rates are still significantly lower. Similarly, although our results find that African American students are more interested in agribusiness management than are Caucasian students, they are underrepresented in these programs relative to the overall undergraduate student body. As female and minority faculty have been found to significantly influence female and minority students in choice of major (Rask and Bailey, 2002), faculty who reflect these groups could be particularly helpful in promotional and recruitment efforts.

Finally, providing informative but accessible written and electronic AAAE materials for high school teachers, counselors, and 4-H and FFA advisors, as well as building relationships not just with agricultural teachers but also with business and economics teachers, could also help foster student interest in this field.

\subsubsection{Recruiting Opportunities: Places}

Consistent with findings from Robinson, Garton, and Washburn (2007) and Rocca and Washburn (2005), high school respondents indicate that they obtain more information about colleges and programs from college websites than from any other source. As such, programs would do well to invest in their online presence as a key marketing tool. When asked to rank the relative importance of website attributes, students prioritize information about program concentrations, job placement of program graduates, and current student testimonials. In order of overall ranking, information about student clubs, general departmental news and events, faculty information, student awards and honors, and alumni news were also deemed important.

Social media was not reported to be a primary information source used by students to gain information about a university or academic program. In focus group discussions, however, students reported using a variety of social media tools such as Facebook and Twitter to keep updated about events and successes of favored schools and programs. Although students cautioned against overuse of 
social media (i.e., frivolous updates and announcements), they generally reported that these tools helped them feel more connected to the campus. Thus, although social media tools may be a relatively minor aid in initial recruiting, they may be effective in building connections with students, which, in turn, may help improve the ratio of enrollment offers to acceptances.

\subsubsection{Recruiting Opportunities: Partners}

Students report that they highly value job placement information. Although department respondents emphasized career opportunities and high rates of placement in their description of their programs, college respondents placed much less emphasis on these outcomes. Departments could help improve the quality of college recruiters' contacts with potential AAAE students by providing them with more information about the breadth of careers available to agricultural and applied economics graduates, job placement rates, and starting salaries. Further, college recruitment staff members recommend that AAAE departments develop and provide informational material for them to share with high school students. Results presented in Table 2 suggest that materials should be developed separately for each program rather than for the AAAE department as a whole. Tailoring materials to be compatible with the source of student interest in a program is also recommended. This approach would suggest that, in the case of agribusiness management, for example, materials be separately developed for those with interest in the program through agriculture and for those with interest because of its connections to the environment.

Industry associations and firms operating in fields that are positively related to student interest in AAAE programs should also be considered as potential recruitment partners. Increasing staff awareness of AAAE programs, activities, and scope may, through informal communication channels, help increase awareness and interest of university-bound students in these programs. An easy point of connection would be to invite a representative from these organizations as a class speaker. Doing so allows for a bidirectional flow of information; students receive information about applications of their chosen field, and there is the opportunity to share information with the speaker about the program(s) that can later be shared (formally or informally) with colleagues.

Fostering industry connections also complements recommendations by several college personnel that AAAE departments implement an internship requirement. Beyond further improving the marketability of program graduates, this requirement would enhance visibility of the discipline and generate testimony to other students of the value of an applied economics education. As one departmental respondent stated, "We believe that providing our current students with an exceptional experience is our best marketing strategy because when they graduate, they become 3-D advertisements for us."

A final and generally underutilized recruitment partner is AAAE alumni networks. Department alumni, in both their professional and personal lives, 
may interact with prospective students and their parents. A gentle reminder to these individuals to share their insight into AAAE programs with their family, friends, and colleagues will help to improve awareness of these programs.

\subsubsection{Recruiting Opportunities: Product}

To expand their appeal and better reflect their breadth of activities, several agricultural economics departments have changed their names in recent years. Many former "agricultural economics" or "agribusiness" departments have replaced "agriculture" with terms such as "applied," "resource," "environment," or "food." Among the participating schools, AAAE programs are known by at least 9 different primary degree names; including options within a major, this number increases to 22 different names. Although these changes reflect the diversity of programs and foci within the discipline, they can complicate cross-institutional comparisons for high school students. Further, college-level recruiters often have a limited understanding of the breadth of many AAAE programs. It is incumbent on departments to clearly and succinctly communicate to both prospective students and college-level recruiters the breadth of educational opportunities offered by AAAE departments.

Also, the distinctive culture of many AAAE programs is underemphasized. AAAE programs offer unique educational opportunities in an often more personal environment than is typically available through comparable business school programs. By way of example, there is frequently a higher focus on meaningful experiential or service learning in AAAE departments than in business programs, which, because of relative student numbers, more frequently rely on simulation exercises. This type of learning can be further augmented through connections with university extension services (Curtis and Mahon, 2010). Given the appeal of these experiences to prospective students (Lester et al., 2005), characteristics of AAAE programs in general, and those unique to each department, should be characterized and communicated to those in positions to contribute to AAAE recruitment.

Employment opportunities should also be emphasized. In our survey, students indicated a high interest in job placement of graduates, ranking it second in importance among online information. For students who consider financial and job security in their choice of major, emphasizing that employment opportunities significantly outnumber qualified graduates and that unemployment is less than $2 \%$ should be particularly attractive.

Departments gifted with scholarship funds or access to college awards should emphasize these opportunities online and in promotional materials. Fees and cost of living were reported to be the second most important factor in influencing students' choice of school; reducing this cost will appeal to both prospective students and their parents. Even if this information is available on the college website, departments are recommended to replicate this information on their 
own website as high school students generally do not understand relationships between these administrative units.

\subsubsection{Recruiting Resources: Capacity Building}

Recognizing the importance of developing quality targeted materials, several AAAE programs have recently increased their capacity in this area. One approach has been to hire a communications manager with responsibilities that include leading the development of new promotional materials, helping to foster and develop relationships with alumni and industry groups, managing social media communications, and developing other communications and promotional materials such as newsletters and media releases. These positions are generally not new staff positions but rather are enabled through reconfiguration of staff duties. Alternatively, some of these activities can be accomplished through collaborations with communications, graphics, and similar programs that have practicum requirements of their graduate or undergraduate programs.

\section{Conclusions}

Despite the unmet demand for their graduates, many AAAE departments still are challenged by recruiting enough undergraduate students to ensure their independent existence and sufficient allocation of resources within colleges of agriculture. Given the desire of many AAAE departments to expand and/or improve the quality of their undergraduate student body, improved recruitment strategies are needed.

AAAE programs typically face the dual challenge of attracting nonagricultural students to colleges of agriculture and steering agricultural students who are predominately interested in natural science into a social science discipline. Most AAAE departments are more broadly focused than they were a generation ago; the inclusion of areas such as development economics, finance, international trade, and resource and environmental economics has expanded the base of potential students and the scope of opportunities for successful graduates. Although this is well known within the profession, students and college professionals often do not realize the discipline's breadth.

Improving awareness and understanding of the discipline, among both students and college and university student services staff who complement department-based recruitment efforts, will be crucial to the sustainability of currently and potentially threatened programs. Achieving this improved awareness and understanding, however, is difficult. Many academic departments are constrained in the time and financial resources needed to develop and keep promotional materials current. In the interest of supporting the discipline as a whole, it is recommended that the discipline's national professional association support department marketing efforts through development of general web videos and templates about career opportunities in the field, unemployment rates of 
graduates from the discipline, and the general role of agricultural and applied economics in the economy. Individual departments could then embed these videos on their websites or adapt these templates to their institutions, thus reducing the marketing burden on departments. Efforts should also be made at the national level to find opportunities to market careers requiring an AAAE background. ${ }^{6}$

If provided with unlimited resources to market AAAE programs, student services personnel reported that they would hire additional staff to help advertise programs through high school visits, provide more outreach activities including specialized events for prospective students and their parents, improve communications with departments, increase social media advertising and announcements, provide job-shadowing opportunities with industry professionals, and improve written marketing literature to demonstrate the business and international applications of AAAE. One respondent suggested creating "a whole campaign of flashy brag pieces to include print and ... videos ... of what business [professionals] really do and how they affect the world and our day-to-day lives (and that it does not mean you have to do your job on a tractor!)."

AAAE departments offer a unique product that should be easily marketable. Successful recruiters, whether at the college or departmental level, need to provide useful information to students about the possibilities, educate them about majors, and engage their interests. An effective strategy will use a mix of marketing techniques. AAEA departments must be clear about what they are "selling" and to whom they are trying to market their programs before designing their marketing strategy. Low unemployment rates, increasing demand for graduates with agricultural and applied economics training, a wide variety of job opportunities, and relatively high salaries for graduates from these programs (Artz, Kimle, and Orazem, 2014) suggest great potential to increase undergraduate enrollment in AAAE programs. To achieve this, we would do well to take the advice that we give to our own agribusiness students-using a holistic approach and a consistent message, we need to dedicate the time and other resources needed to better market ourselves.

\section{References}

Artz, G.M, K.L. Kimle, and P.F. Orazem. "Does the Jack of All Trades Hold the Winning Hand? Comparing the Role of Specialized verses General Skills in the Returns to an Agricultural Degree." American Journal of Agricultural Economics 96,1(2014):193212.

6 One ambitious example would be to find ways to get AAAE-related positions profiled in mainstream media and entertainment through television shows such as Undercover Boss. As one staff respondent aptly noted, "If there's a TV show about it, students will know what it is!" 
Baker, L.M., T. Irani, and K. Abrams. "Communicating Strategically with Generation Me: Aligning Students' Career Needs with Communication about Academic Programs and Available Careers.” NACTA Journal 55,2(2011):32-39.

Brown, R.C., M.Y. Hernández, T.D. Mitchell, and C.R. Turner. "Factors Influencing Student Choice Between In-State and Out-of-State Students." Journal of the Indiana University Student Personnel Association 1999:30-44.

Chapman, D.W. "A Mode of Student College Choice." Journal of Higher Education 52,5(1981):490-505.

Cole, L., and G.W. Thompson. "Survey of Current Students: Implications for Recruitment and Retention." NACTA Journal 43,3(1999):15-20.

Curtis, K., and J. Mahon. "Using Extension Fieldwork to Incorporate Experiential Learning into University Coursework." Journal of Extension 48,2(2010):2FEA4.

DesJardins, S.L., H. Dundar, and D.D. Hendel. "Modeling the College Application Decision Process in a Land-Grant University." Economics of Education Review 18,1(1999):11732.

Dillman, D.A., J.D. Smyth, and L.M. Christian. Internet, Mail and Mixed-Mode Surveys: The Tailored Design Method. 3rd ed. Hoboken, NJ: John Wiley and Sons, 2009.

Fraze, L.B., T. Rutherford, G. Wingenbach, and L.A. Wolfskill. "Urban High School Students' Perceptions about Agricultural Careers and General Agricultural Knowledge.” NACTA Journal 55,4(2011):75-81.

Georgetown University Center on Education and the Workforce. 2011. Internet site: https://cew.georgetown.edu/wp-content/uploads/2014/11/whatsitworth-complete.pdf (Accessed June 15, 2015).

Gilmore, J.L., A.D. Goecker, E. Smith, and P.G. Smith. "Shifts in the Production and Employment of Baccalaureate Degree Graduates from U.S. Colleges of Agriculture and Natural Resources, 1990-2005." Background paper for "A Leadership Summit to Effect Change in Teaching and Learning," National Academy of Sciences, Washington, DC, October 3-5, 2006.

Goecker, A.D., E. Smith, J.M. Fernandez, R. Ali, and R. Goetz. "Employment Opportunities for College Graduates in Food, Agriculture, Renewable Natural Resources, and the Environment: United States, 2015-2020.” Internet site: https://www.purdue.edu/usda/employment/ (Accessed May 26, 2015).

Goecker, A.D., P.G. Smith, E. Smith, and R. Goetz. 2010. "Employment Opportunities for College Graduates in Food, Renewable Energy, and the Environment: United States, 2010-2015." Internet site: http://www3.ag.purdue.edu/USDA/employment/ Documents/USDA_Employ_Op_2010_8_LREZ.pdf (Accessed May 26, 2015).

Green, W.H. Econometric Analysis. 7 th ed. Upper Saddle River, NJ: Prentice Hall, 2011.

Herren, C.D., D.D. Cartmell II, and J.T. Robertson. "Perceptions of Influence on College Choice by Students Enrolled in a College of Agricultural Sciences and Natural Resources." NACTA Journal 55,3(2011):54-60.

Lester, S.W., C. Tomovick, T. Wells, L. Flunker, and J. Kickul. "Does Service-Learning Add Value? Examining the Perspective of Multiple Stakeholders." Academy of Management Learning \& Education 4(2005):278-94.

Morgan, D.L., and R.A. Krueger. The Focus Group Kit. Thousand Oaks, CA: Sage, 1998.

Perry, G.M. "What Is the Future of Agricultural Economics Departments and the Agricultural and Applied Economics Association?" Applied Economic Perspectives and Policy 32,1(2010):117-34. 
Qualtrics Labs. Qualtrics [Computer software]. Version 2011. Provo, UT: Qualtrics Labs.

Rask, K., and E. Bailey. "Are Faculty Role Models? Evidence from Major Choice in an Undergraduate Institution." Journal of Economics of Education 33(2002):99124.

Robinson, J.S., B.L. Garton, and S.G. Washburn. "The Influential Factors First-Time Enrollees Utilize When Choosing a College of Agriculture." NACTA Journal 51,2(2007): 27-33.

Rocca, S.J., and S.G. Washburn. "Factors Influencing College Choice of High School and Transfer Matriculants into a College of Agriculture." NACTA Journal 49,1(2005):3238.

Seidman, I. Interviewing as Qualitative Research: A Guide for Researchers in Education and the Social Sciences. 3rd ed. New York: Teachers College Press, Columbia University, 2006.

Sujan, M. "Consumer Knowledge: Effects on Evaluation Strategies Mediating Consumer Judgments." Journal of Consumer Research 12,1(1985):31-46.

Tarpley, R.S., and R.L. Miller. "Factors Associated with the Choice of College Major in Utah.” NACTA Journal 48,2(2004):13-16.

U.S. Census Bureau. "Annual State Resident Population Estimates for 6 Race Groups (5 Race Alone Groups and Two or More Races) by Age, Sex, and Hispanic Origin: April 1, 2000 to July 1, 2010 (SC-EST2010-ALLDATA6).” Washington, DC: U.S. Census Bureau, 2010. Internet site: https://www.census.gov/popest/research/ eval-estimates/eval-est2010.html (Accessed February 10, 2015).

U.S. Census Bureau, County Business Patterns. Washington D.C.: U.S. Census Bureau 2011. Internet site: http://www.census.gov/econ/cbp (Accessed June 15, 2015).

U.S. Census Bureau. "Lists of Population, Land Area, and Percent Urban and Rural in 2010 and Changes from 2000 to 2010.” Washington D.C.: U.S. Census Bureau 2010. Internet site: http://www.census.gov/geo/reference/ua/urban-rural-2010.html (Accessed June 15, 2015).

U.S. Census Bureau. "Urban, Urbanized Area, Urban Cluster, and Rural Population, 2010 and 2000: United States" and "Lists of Population, Land Area, and Percent Urban and Rural in 2010 and Changes from 2000 to 2010.” Washington D.C.: U.S. Census Bureau 2010. Internet site: http://www.census.gov/geo/reference/ua/urban-rural-2010.html (Accessed June 15, 2015).

U.S. Department of Agriculture, Economic Research Service. "Agriculture Resource Management Survey (ARMS): Resource Regions.” 2010. Internet site: http:// webarchives.cdlib.org/wayback.public/UERS_ag_1/20111128195215/http:/www.ers. usda.gov/Briefing/ARMS/resourceregions/resourceregions.htm (Accessed January 5, 2014).

U.S. Department of Agriculture, Economic Research Service. "Rural-Urban Continuum Codes.” 2013. Internet site: http://www.ers.usda.gov/data-products/ rural-urban-continuum-codes/.aspx (Accessed May 26, 2015). 


\section{Appendix}

Table A1. Variable Definitions and Descriptions

\begin{tabular}{|c|c|c|}
\hline Variable & Variable Description & Details \\
\hline \multicolumn{3}{|c|}{ Student and household characteristics } \\
\hline Age & Student age & $\begin{array}{l}\text { Values } 1-10, \text { where } 1=14 \text { years, } \\
2=15 \text { years, etc. }\end{array}$ \\
\hline Female $^{\mathrm{a}}$ & Gender & $1=$ Female, $0=$ male \\
\hline AfricanAmerican ${ }^{a}$ & Race/ethnicity & $\begin{array}{l}1=\text { African American, } 0=\text { not } \\
\text { African American }\end{array}$ \\
\hline HSYear & Current year in high school & $\begin{array}{l}\text { Values } 1-4 \text {, where } 1=\text { senior, } 2= \\
\text { junior, } 3=\text { sophomore, } 4= \\
\text { freshman }\end{array}$ \\
\hline HHMembers & $\begin{array}{l}\text { Number of people in } \\
\text { household }\end{array}$ & Number of members \\
\hline Siblings & $\begin{array}{l}\text { Student has siblings who } \\
\text { currently or plan to go to } \\
\text { university }\end{array}$ & $1=$ Yes, $0=$ no \\
\hline HHIncome & Household income & $\begin{array}{l}\text { Categorical variable: } 7 \text { categories, } \\
1=<\$ 25 \mathrm{~K} \ldots 7=>\$ 200 \mathrm{~K}\end{array}$ \\
\hline StudyHours & Weekly hours spent studying & $1=<5 \mathrm{~h}, 2=5-10 \mathrm{~h}, 3=>10 \mathrm{~h}$ \\
\hline GPA & Cumulative GPA & GPA \\
\hline RUCC & $\begin{array}{l}\text { Rural-Urban Continuum } \\
\text { Codes }\end{array}$ & $\begin{array}{l}\text { Values 1-8. Relative rurality of } \\
\text { the respondent's home country } \\
\text { was assessed using the U.S. } \\
\text { Department of Agriculture } \\
\text { (USDA) Rural-Urban } \\
\text { Continuum Codes (USDA, } \\
\text { Economic Research Service, } \\
\text { 2013). }\end{array}$ \\
\hline BothAttendUniv ${ }^{\mathrm{a}}$ & $\begin{array}{l}\text { Both parents attended } \\
\text { university }\end{array}$ & $\begin{array}{l}1=\text { Both parents attended } \\
\text { university, } 0=\text { not }\end{array}$ \\
\hline MomAttendUniv & Mother attended university & $\begin{array}{l}1=\text { Mother attended university } \\
0=\text { not }\end{array}$ \\
\hline DadAttendUniv & Father attended university & $\begin{array}{l}1=\text { Father attended university, } \\
0=\text { not }\end{array}$ \\
\hline PEmploy:Industry ${ }^{\mathrm{a}}$ & $\begin{array}{l}\text { Parent employment in noted } \\
\text { industry }\end{array}$ & $\begin{array}{l}1 \text { = Yes, } 0=\text { no. At least one } \\
\text { parent employed in the noted } \\
\text { industry; } 23 \text { industry } \\
\text { classifications considered. }\end{array}$ \\
\hline
\end{tabular}


Table A1. Continued

Variable

Student and household

characteristics

Variable Description

Details

Student activities

Participate:AgClass ${ }^{\mathrm{a}}$

Participate(d) in agriculture class

Participate:AgExtra ${ }^{a}$

Participate(d) in agriculture extracurricular activity

Participate:EnvClass ${ }^{\mathrm{a}}$

Participate(d) in

$1=$ Yes, $0=$ No

Participate:EnvExtra ${ }^{\mathrm{a}}$ environment class

Participate(d) in agriculture extracurricular activity

Student field of study and program interests

Interest_Business ${ }^{\mathrm{a}}$

Interest_Economics ${ }^{\mathrm{a}}$

Interest_ProgApEcon ${ }^{\mathrm{a}, \mathrm{b}}$

Interest_ProgENRE ${ }^{\mathrm{a}, \mathrm{b}}$

Interest_ProgAgEcon ${ }^{\mathrm{a}, \mathrm{b}}$

Interest_ProgAgMgmt ${ }^{\mathrm{a}, \mathrm{b}}$
Field of study: high interest in business

Field of study: high interest in economics

Program: high interest in applied economics

Program: high interest in environmental and natural resource economics

Program: high interest in agricultural economics

Program: high interest in agribusiness management
Five-point Likert scale evaluating level of interest in field. Rating of 4 ("very") or 5 ("extremely") $=1$. Rating of 3

("moderately"), 2 ("somewhat"), or 1 ("not at all”) $=0$.

${ }^{a}$ Included in final models.

${ }^{b}$ Evaluated as a dependent variable in probit analysis. 